Journal of Educational Research in Developing Areas (JEREDA)

Vol. 2. Issue 2, Pp. 100-109, 2021

http://www.jeredajournal.com

E-mail: info@jeredajournal.com

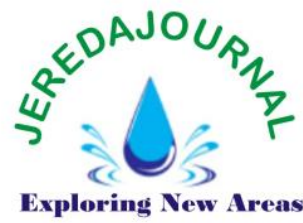

Research Article DOI: https://doi.org/10.47434/JEREDA.

eISSN : $2735-9107$

\title{
INQUIRY BASED METHOD ON ACADEMIC ACHIEVEMENT OF BIOLOGY STUDENTS AT SECONDARY LEVEL IN HAZARA DIVISON, PAKISTAN
}

\author{
1*Zahid Mehboob, ${ }^{2}$ Misbah Mehboob, ${ }^{3}$ Motunrayo Iyabode Adeyemi \\ ${ }^{1 *}$ Department of Institute of Molecular Biology and Biotechnology, University of Lahore, \\ Pakistan \\ ${ }^{2}$ Department of Education, Hazara University Mansehra, Pakistan \\ ${ }^{3}$ Federal College of Education (Special), Oyo, Nigeria \\ 1*zahidmhboob1223@gmail.com; 2misbahmehboob89@gmail.com, \\ 3tunrayoadeyemi69@gmail.com \\ *Corresponding author: ${ }^{1 *}$ zahidmhboob1223@gmail.com
}

Received: $12^{\text {th }}$ May, 2021; Revised:24th May, 2021; Accepted: $4^{\text {th }}$ June, 2021

ABSTRACT

Introduction: Inquiry based method is one of the innovations in teaching techniques. Despite its benefits, inquiry based method has not got due popularity in the Pakistani context.

Purpose: The objectives of the study were: to examine the effects of Inquiry Based Method on the academic achievement of students Biology at secondary level, to compare the academic achievement of low-achievers of Biology at secondary level taught through inquiry Based Method and Lecture Method, and to compare the academic achievement of high-achievers of Biology of secondary level taught through Inquiry Based Method and Lecture Method.

Methodology: Two null hypotheses were formulated in order to achieve the objectives. One hundred twenty (120) science students of grade $10^{\text {th }}(2017-2018)$ from GGHS No. 2 Haripur were considered as population. Sixty (60) Science students of grade $10^{\text {th }}$ from GGHS No. 2 Haripur were selected as sample of the study. These students were divided into two equivalent groups i.e. control $(n=30)$ and experimental group $(n=30)$ on the basis of mean scores of pre \& post- test on Biology. Experimental group was taught through Inquiry Based Method and control group was taught by Traditional Lecture Method for eight weeks.

Results: The analyzed data revealed that experimental group significantly performed better than the control group. Similarly, the lower achievers of experimental group showed significantly better performance than lower achievers of the control group.

Recommendations: It was recommended that teachers who are teaching Biology at secondary school level may be trained to teach Biology by applying Inquiry group learning method.

Keywords: Biology, Inquiry-Based Method, Academic Achievement, Lower Achievers, Higher Achievers.

Crossref Mehboob, Z., Mehboob, M., \& Adeyemi, M. I. (2021). Inquiry based Cited-by method on academic achievement of Biology students at secondary level in Hazara divison, Pakistan. Journal of Educational Research in Developing Areas, 2 (2), 100-109. https://doi.org/10.47434/JEREDA.2.2.2021.100.

Copyright (c) 2021 The author(s) of this article retain(s) the copyright. 


\section{PUBLIC INTEREST STATEMENT}

The study will play a vital role to teach all skills needed for learning Science subjects and to foster curiosity in Biology. The study will also deepen students' understanding of Bio topics and will enable them to take ownership of their learning in the field of Biology. The study is very important for students and teachers to increase engagement with Biology materials and to create a love of learning Biology. It is very important for the students to enhance their approach of inquiry. The research is very significant for the teachers to polish their inquiry techniques and levels. Policy makers and governments at all level will implement inquiry based method while teaching science subjects at Secondary level in Harzara Division, Pakistan.

\section{INTRODUCTION}

Education at secondary level plays a vital role in a student's life. At this level, students' educational career is bifurcated into two main groups: Science Group and Humanities Group. Science subjects like Physics, Chemistry \& Biology are normally considered complex subjects. Especially Biology, because of its terminologies and practical nature, it becomes difficult to teach and learn for both teachers and students. The teacher can positively promote students' skills in the field of Biology by initializing inquiry activities and instructing them with Biological issues. Bransford, Sherwood, Hasselbring, Kinzer and Williams (2012) describe that social interactions can design the learning process itself, although group learning has been heralded as a productive strategy to enhance students' learning, continuing learning material, critical reasoning and motivation (American Association for the Advancement of Science, 1989). According to Bloom (1956) understanding of the students is not thoroughly checked through lecture-based instructional strategy. The Lecturer maintains his/her talk often and seldom permits the students in oral participation during the lecture. In lecture-based instruction strategy, students face difficulty in fixing about what is the essential part of the lecture for the preparation of examination because the course content is often presented in an improper and unidentified way.

Science education embodies an important part of a child's formal and informal education. In order to solve daily problems, children are, consciously or unconsciously, busy in scientific thinking and analysis of situations. This scientific approach for solving everyday issues requires encouragement in a formal educational setting where teachers consistently vary and formulate curriculum and instruction to meet the requirements of their children (Poon \& Tan, 2009). The best environment that fosters and promotes structured scientific reasoning and thinking is the school where the child spends the major part of his/her day when he/she is away from home. It is within the school environment that formal learning takes place. Standard attitudes and values which the child inculcates are transformed by the teacher who is distinctively trained to instruct at the given grades. There exists research done by professional teachers and theorists who suggest statements and provide proof in support of both the inquiry method and direct instruction method of teaching science.

Vygotsky (1980) elaborated in the class for a social content where the learner performs talks with the peer group. Kolb (1984) stressed reflection upon experience, and Fielding (2012) emphasized on the inquiry learning. Inquiry-Based Teaching (IBT) approach is used to state teaching strategies that are taken by scientific inquiry. The approach is based on constructivist teaching practices. It is student-centered rather than teacher-centered and presents the chance for students to be actively engaged in experimenting, interrogation and researching. The approach has been regarded as being able to enhance motivation among secondary school students as it creates interest in the process of obtaining scientific knowledge and skills (Gibson \& Chase, 2002). Research's outcomes indicate that 
Inquiry-Based Training (IBT) may be very productive in promoting students' achievement, motivation and critical reasoning to learn science as well as enhancement of scientific process skills (Alleman, Brophy \& Knighton, 2008).

Safdar (2013) describes that traditional lecture method is the most preferred method of teaching in science classrooms in Pakistan where the students are required to inculcate material and facts in the science subjects and reproduce in the examination. As a result, students lack an innate ability to build their own thinking about scientific phenomenon and linkage of various notions to describe scientific incidents. This also leads to disregard scientific process and motivation to learn science because science learning is more than the memorization of scientific facts and information but rather it is about understanding and applying scientific concepts and methods (Bell, Urhahne, Schanze, \& Ploetzner, 2010). Biological Science Curriculum Study (BSCS) developed a practical model of teaching by inquiry which is called the 5Es model. The constructivist philosophy of learning provided the base for this model. Every $E$ represents a part of the learning process which is designed to help the students in increasing their knowledge and learning experience. 5Es model has the following phases: Engagement, Exploration, Explanation, Elaboration and Evaluation. The general aims and activities of five stages of the model as presented by Bybee, Taylor, Gardner, Van Scotter, Powell, Westbrook and Landes (2006) are as given below:

At the phase of engagement, the teacher mainly asks interesting, motivating and enthusiastic questions about the relevant topic to keep the class remain focused on all their intellectual commitment. At this stage, the teacher is not keeping attention only on the correct answer but more interested in the previous information about the topic and the ambition of the students to know more facts. This helps to reinforce the attention of the students on the crust of the facts that are the source of real knowledge that are directly touching the rational aspect of the mind. This approach activates the mind of students to inspire their mental and physical faculties (Cavallo, Miller \& Saunders, 2002). During the exploration step, students are enabled to understand different aspects of learning and they now acquire the ability to solve the problem independently and they synthesized different concepts to fit into the present situation. The students get involved in the purposeful exchange of ideas and are now quite fit to accept the relevant material and relegate the irrelevant material into the background. In this situation, the role of the teacher is like a facilitator and a guide (Miller \& Sambell, 2003).

During the explanation series, the students' involvement is focused on the learning process and is more productive than one person can show the teacher in the traditional outmoded classroom. This makes the tough learning process quite easy as the students themselves shift, explain, relate and conclude in the light of their exploration and investigation to make the learning closely related to their past attainments and the present achievements by their direct and active involvement (Bybee, 2006). In the elaboration stage, the teacher reviews and elaborates the learner' notion about techniques of science. Learners acquire accurate comprehension due to their own experience and also adopt enough scientific and problem solving techniques. Learners undertake further activities and apply their scientific notions. Students pursue acquiring concepts and become capable to match the recently acquired concepts with newly learned concepts. Champagne (1987) pointed out that at this point learners are indulged in discussion and various other activities to acquire knowledge and learning.

At the conclusion stage, the teacher also gets involved. Through an academic achievement process of students and teachers, the joint efforts bear fruit for purposeful learning through a common approach (Bybee, 2000). Inquiry method usually ends at the assessment of the students in the material they have learned. The last step 
of teaching through inquiry method is evaluation. The teacher surmises and evaluates the knowledge of learners about the current topic. Such an evaluation is based on the learning or instructional motives. The teacher can utilize either formal or informal evaluation separately or both types of evaluation at the same time. This type of evaluation is also related to the scientific inquiry and application of knowledge in carrying out the inquiries concerned with science (BSCS, 2006). It is against these background that the researchers intend to find the effect of inquiry based method on academic achievement of biology students at secondary level in Hazara Divison, Pakistan.

\section{STATEMENT OF THE PROBLEM}

Inquiry based method is one of the innovations in teaching techniques. Despite its benefits, inquiry based method has not got due popularity in the Pakistani context. There has been scarce research on this method in Pakistan. The present study, therefore, aimed to explore the effectiveness of inquiry based method in teaching Biology at the secondary school level in Hazara Division. This is done in terms of the impact of inquiry based teaching on the academic achievement of students in Biology at the secondary school level.

\section{PURPOSE OF THE STUDY}

1. To examine the effectiveness of inquiry based method on academic achievement of students in Biology at secondary level.

2. To compare the academic achievement of low-achievers in Biology of secondary level taught through inquiry-based method and lecture method.

3. To compare the academic achievement of high-achievers in Biology of secondary level taught through inquiry based method and lecture method.

\section{HYPOTHESES}

1. There is no significant difference between experimental and control groups on achievement mean scores of students in Biology at Secondary level.

2. There is no significant difference between low-achievers of experimental and control groups with respect to achievement mean scores in Biology at Secondary level.

3. There is no significant difference between the high- achievers of the experimental and control groups with respect to achievement mean scores in Biology at Secondary level

\section{METHODOLOGY \\ Research Design}

The Pre-test, Post-test equivalent group design was used for the study. In case of natural sciences like Biology, Chemistry and Physics etc, this design is more useful as compared to other experimental designs because it administers to exclude external variables and other inappropriate sources of variation (Gay, Mills \& Airasian, 2009). The experimental and control groups of students were formed on the basis of mean' scores in achievement test for Biology.

\section{Population and Sample}

One hundred and twenty (120) students studying Biology at grade $10^{\text {th }}$ (session, 2017-2018) of Government Girls High Schools No 2 Haripur were the population of the study. Sixty (60) students of grade $10^{\text {th }}$ from GGHS No 2 (Haripur District) were selected as sample of the study. These students were divided in to two groups, experimental and control groups. Both groups were selected on the basis of mean scores of achievement test of Biology by using a matched random sampling technique. These students were of the same age group having heterogeneous ability in Biology.

\section{Instruments for Data Collection}

An achievement test (Pre-test and Post-test) was developed as research instrument. The test covered the last four chapters (Inheritance, Man and his Environment, Biotechnology and 
Pharmacology) of the Textbook for $10^{\text {th }}$ grade prescribed by KP Textbook Board Peshawar. This test was composed of multiple choice questions, short answers and labeling the diagram. Pre-test serve as source of forming group while posttest was used after seven weeks when the treatment was over. Content validity of the test was approved by experts in the field. Therefore, the researchers consulted subject experts and subject teachers in the field of Biology for validating the test. Further, the researchers studied the literature for the construction of valid items. These items were finalized on the opinion of these experts in order to construct a valid test. Reliability of the test was measured by using split-half (odd-even) technique. The test items were divided into two halves ensuring that each half will match in terms of item difficulty and content. Each half was marked separately. The reliability was calculated by using Spearman-Brown formula: Reliability = $2 r / 1+r=0.892$, where $r=$ the actual correlation between the halves of the instrument.

\section{Procedure for Data Collection}

Data was collected through research made pre-test and post-test. Researchers had obtained permission from District Education Office and Principals concerned for data collection. Pre-test score was used equally to distribute students in the experimental and control groups while post-test were served at the end of the experiment in order to know the achievements of students in both groups. The pre-test was administered to 60 students selected out of two sections of $10^{\text {th }}$ class studying in GGHS No. 2 Haripur. The students were divided into two groups by equating them on the marks obtained in pre-test. Thus, each group comprised of 30 students. The two groups were randomly assigned to the experimental and control groups. Both the groups were allocated to the classrooms which were equal in all respect. Both groups were taught the same content as included in the last four chapters of Biology. The subject was taught in the fourth period according to the timetable. The duration of one period was 40 minutes. Both groups were provided equal facilities and teaching environment except that method of teaching was different. The experimental group was taught through inquiry based method whereas the control group was taught through traditional method. The duration of the experiment was eight weeks which was found adequate for teaching the selected chapter to the students. The same achievement test was administered to the experimental and control group as post-test at the end of the treatment.

After grouping the students in the class, the experimental group was given a treatment of inquiry teaching method and control group was taught by traditional lecture method for teaching Biology grade $10^{\text {th }}$. The experimental group was taught in science laboratory through inquiry group learning method and control group was taught in the classroom by the traditional lecture method. Science apparatus, instruments and devices were used. Data obtained were analyzed by applying t-test of independent sample by using SPSS version-16.

\section{RESULTS}

Hypothesis 1: There is no significant difference between experimental and control groups on achievement mean scores of students in Biology at Secondary level. 
Journal of Educational Research in Developing Areas (JEREDA)

Vol. 2. Issue 2, Pp. 100-109, 2021

http://www.jeredajournal.com

E-mail: info@jeredajournal.com

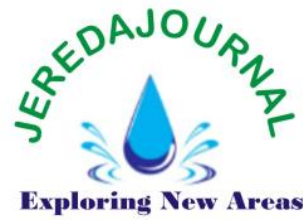

Table 1: Comparison between academic achievement scores of Experimental and control group on pre-test of academic achievement in Biology

\begin{tabular}{lcccccc}
\hline Groups & N & Mean & S.D & t-value & df & p-value \\
\hline Control Group & 30 & 29.67 & 7.28 & & & \\
& & & & 0.170 & 58 & 0.865 \\
Experimental Group & 30 & 30 & 7.85 & & &
\end{tabular}

Note: The Value is significant if $\mathrm{P} \leq \alpha=0.05$

Table 1 indicates that since $P$ value $0.86>0.05$ which means that there is no significant difference between academic achievement of experimental and control group in Biology. The mean academic achievement scores of experimental group was 30 while control group was 29.67.

Table 2

Comparison between the academic achievement scores of experimental and control on post-test in academic achievement in Subject of Biology

\begin{tabular}{lcccccr}
\hline Groups & N & Mean & S.D & t-value & df & p-value \\
\hline Control Group & 30 & 52.17 & 12.11 & & & \\
& & & & 0.275 & 58 & 0.045 \\
Experimental Group & 30 & 55.03 & 10.319 & & & \\
\hline
\end{tabular}

Table 2 presents that since $\mathrm{P}$ value $0.045>0.050$ which means that there is significant difference between academic achievement of experimental and control group in Biology. The mean academic achievement scores of experimental group was 55.03 while control group was 52.17.
Hypothesis 2: There is no significant difference between low-achievers of experimental and control groups with respect to achievement mean scores in Biology at Secondary level.

Table 3: Comparison between the pre-test academic achievement scores of low- achievers of experimental and control group on the achievement of students in Biology

\begin{tabular}{lcccccc}
\hline Groups & N & Mean & S.D & t-value & df & p-value \\
\hline Control Group & 8 & 20.50 & 3.96 & & & \\
& & & & 0.233 & 14 & 0.819 \\
Experimental Group & 8 & 19.88 & 6.46 & & & \\
\hline
\end{tabular}


Journal of Educational Research in Developing Areas (JEREDA)

Vol. 2. Issue 2, Pp. 100-109, 2021

http://www.jeredajournal.com

E-mail: info@jeredajournal.com

Table 3 presents that since $P$ value $0.819>0.05$ which means that there is no significant difference between academic achievement of experimental and control group in the subject of biology. The mean scores of lowachievers of experimental group was 19.88 while control group was 20.50 .

Table 4: Comparison between the post-test academic achievement scores of low-achievers of experimental and control group on the achievement of student in the subject of Biology

\begin{tabular}{lcccccc}
\hline Groups & N & Mean & S.D & t-value & df & p-value \\
\hline Control Group & 8 & 37.39 & 4.37 & & & \\
& & & & 0.622 & 14 & 0.37 \\
Experimental Group & 8 & 37.00 & 9.65 & & & \\
\hline
\end{tabular}

Table 4 depicts that since P-value $0.37>0.05$ which means that there is no significant difference between academic achievement of experimental and control group in the subject of Biology. The mean scores of low-achievers of experimental group was 37.00 while control group was 37.39.
Hypothesis 3: There is no significant difference between the high- achievers of the experimental and control groups with respect to achievement mean scores in Biology at Secondary level

Table 5: Comparison between the pre-test academic achievement scores of high-achievers of experimental and control group on the achievement of student in the subject of Biology

\begin{tabular}{|c|c|c|c|c|c|c|}
\hline Groups & $\mathbf{N}$ & Mean & S.D & t-value & df & p-value \\
\hline \multirow[t]{2}{*}{ Control Group } & 8 & 37.12 & 1.55 & \multirow{3}{*}{-1.29} & \multirow{3}{*}{14} & \multirow{3}{*}{0.217} \\
\hline & & & & & & \\
\hline Experimental Group & 8 & 38.25 & 1.90 & & & \\
\hline $\begin{array}{r}\text { Table } 5 \text { pre } \\
\text { value } 0.217>0.0 \\
\text { there is no significar }\end{array}$ & & $\begin{array}{l}\text { ce } P- \\
\text { that } \\
\text { ween }\end{array}$ & $\begin{array}{l}\text { and cc } \\
\text { biology } \\
\text { achieve } \\
38.25 \mathrm{v}\end{array}$ & \multicolumn{3}{|c|}{$\begin{array}{l}\text { group in the subject of } \\
\text { e mean scores of high- } \\
\text { f experimental group was } \\
\text { control group was } 37.12 \text {. }\end{array}$} \\
\hline
\end{tabular}
academic achievement of experimental

Table 6: Comparison between the post-test academic achievement scores of high-achievers of experimental and control group on the achievement of student in the subject of Biology

\begin{tabular}{lcccccc}
\hline Groups & N & Mean & S.D & t-value & Df & p-value \\
\hline Control Group & 8 & 67 & 6.71 & \multirow{2}{*}{0.109} & 14 & 0.04 \\
Experimental Group & 8 & 69.33 & 4.7 & & & \\
\hline
\end{tabular}


Table 6 depicts that since P-value $0.04<0.05$ which means that there is significant difference between academic achievement of experimental and control group in the subject of Biology. The mean scores of high-achievers of experimental group was 69.33 while control group was 67.00 .

\section{DISCUSSIONS}

To examine the effectiveness of inquiry based method on academic achievement of students in the subject of Biology at secondary level. The analysis between post scores of experimental and control groups on the achievement was significant at 0.05 level and the null hypothesis. The result showed that there was no significant difference between the mean scores of experimental and control groups on achievement of students in Biology at Grade-10 on post-test. These finding of the study are similar to the findings of the study conducted by Hashmi, Hussain and Shoaib (2018) in which they found a significant effect of treatment (guided, unguided and combination scientist inquiry) on students' academic achievement. Similarly, these findings are in line with the results of study conducted by Ozgelen, Yilmaz-Tuzun and Hanuscin (2013), in which they found inquiry based learning as more effective method of teaching as compared to traditional lecture method.

To compare the academic achievement of low-achievers in Biology of secondary level taught through inquiry based method and lecture method. The difference between mean post test scores of low-achievers of experimental group and control group was significant at 0.05 levels. Hence the null hypothesis that there was no significant deference between mean scores of low- achievers of experimental and control groups with respect to achievement in Biology on post-test at Grade-10" on post- test was rejected. Therefore, this study confirms the study of Yager and Simmons (2013) in which low-achievers of experimental group performed better than lowachievers of control group in speaking skills.
To compare the academic achievement of high-achievers in Biology of secondary level taught through inquiry based method and lecture method. The difference between post score of highachievers of experimental group and control group was significant at 0.05 levels. Hence the null hypothesis that there was no significant difference between the mean scores of highachievers of the experimental and control groups with respect to achievement in Biology on post-test at Grade-10" on post- test was rejected. Same were the findings in studies conducted by Zareen and Kayani (2014); Savery (2015).

\section{CONCLUSION}

The present study deals with the investigation of the objectives of study which was to study the effect of inquiry based method on academic achievement of students in Biology at Secondary school level. One hundred twenty students of grade $10^{\text {th }}$ were selected as the sample from Government Girls High School No. 2 Haripur. A test of inquiry based method was designed from the $10^{\text {th }}$ grade Biology book which was consisted of 66items. The reliability of pre- test was checked by Cranach's $\alpha$ which was 0.733 scales. Both groups were taught by the researchers on the basis of pre and post- test for mean scores. For this purpose, two equal groups were formed. One group was taken as experimental or treatment group and another group was treated as a control group. The student participated in the experimental group were taught through inquiry group method and control group was taught through traditional lecture method for a period of 8 weeks from 15 Nov, 2017 to 15 Jan, 2018. The data analyzed was represented in various tables by applying T-test. The analyzed data revealed that experimental group significantly performed better than the control group. Similarly, the lower achievers of experimental group showed significantly better performance than lower achievers of the control group and higher achievers of the experimental group also showed higher achievement than their counterpart in the control 
group. Finally, it proved to be an effective method of teaching Biology at secondary level.

Overall, inquiry teaching method has proved to be effective in teaching methodology with its positive results except for low-achievers. It can be said that in the near future, inquiry teaching methods may be comprised on effective teaching methodologies for developing deep conceptual understanding with long retention, active participation, problem solving skills, decision making, confidence in students' abilities, creating interest, inspiration and achieving goals within a short time among students of Biology at secondary level.

\section{RECOMMENDATIONS}

1. Inquiry teaching method has proved to be effective for learning Biology at secondary school level. Therefore it is recommended for Secondary School teacher to apply this method more frequently in the classroom for teaching science subject of Biology.

2. It is recommended that teachers who are teaching Biology at secondary school level may be trained to teach Biology by applying Inquiry group learning method.

3. Teachers may encourage students to ask questions and discuss the content and other related issues in the class.

4. Further research can open doors to investigate whether inquiry group learning method plays a purposeful role in the traditional classroom setting to upgrade students' understanding and inspiration towards the Biology subject.

\section{Conflicts of Interest}

The authors declare no conflict of interest.

Notes on Authors:

Zahid Mehboob, is a tutor at Allama Iqbal Open University Islamabad Pakistan.

Misbah Mehboob has an M.Phil in Education and graduated from Hazara University Mansehra Pakistan in the year 2018.

Motunrayo Iyabode Adeyemi is an educationist and a researcher with HND
BSc Biochemistry, PGDE and M. Ed certificates. She works with Federal College of Education, (Special), Oyo.Oyo State. She is an executive member of Science Teacher Association of Nigeria; Teacher Registration Council of Nigeria.

Authorship and Level of Contribution: Misbah Mehboob coined the title, raised the hypotheses, designed the study and compiled the manuscript.

Zahid Mehboob partook in the write up of the introduction, statement of the problem, purpose of the study and review of extant literature.

Motunrayo Iyabode Adeyemi did the analysis, testing of the hypothesis, generate the results and interpretation. She came up with the conclusion and the recommendations for the study.

Disclaimer Statement: We hereby declare that this paper is our autonomous work. All texts either quoted directly or paraphrased have been indicated by intext citations. Full bibliographic details are given in the reference list. The study has been written from the M.Phil thesis work conducted in 2018 at Hazara University Mansehra Pakistan under the supervision of Dr javed Iqbal Assistant Professor KPK Pakistan.

\section{REFERENCES}

American Association for the Advancement of Science. (1990). Science for all Americans.

Bell, T., Urhahne, D., Schanze, S., \& Ploetzner, R. (2010). Collaborative inquiry learning: Models, tools, and challenges. International Journal of Science Education, 32(3), 349-377.

Bloom, B. S. (1956). Taxonomy of educational objectives. Vol. 1: Cognitive domain. New York: McKay, 20-24.

Bransford, J. D., Sherwood, R. D., Hasselbring, T. S., Kinzer, C. K., \& Williams, S. M. (2012). Anchored instruction: Why we need it and how technology can help. In Cognition, education, and multimedia (pp. 129-156). Routledge.

Bybee, R. W., Taylor, J. A., Gardner, A., Van Scotter, P., Powell, J. C., 
Westbrook, A., \& Landes, N. (2006). The BSCS 5E instructional model: Origins and effectiveness. Colorado Springs, Co: BSCS, 5, 88-98.

Bybee, R. W. (2006). Scientific inquiry and science teaching. In Scientific inquiry and nature of science (pp. 1-14). Springer, Dordrecht.

Cavallo, A. M., Miller, R. B., \& Saunders, G. (2002). Motivation and affect toward learning science among preservice elementary school teachers: Implications for classroom teaching. Journal of Elementary Science Education, 14(2), 25-38.

Champagne, A. (1987). The psychological basis for a model of science instruction. Commissioned paper for IBM-supported design project. Colorado Springs, CO: Biological Sciences Curriculum Study.

Fielding, M. (2012). Beyond student voice: patterns of partnership and the demands of deep democracy: Más allá de la voz del alumnado: patrones de colaboración y las exigencias de la democracia profunda. Ministerio de Educación. Revista de educación, 359, 45-65.

Gay, L. R., Mills, G. E., \& Airasian, P. W. (2009). Educational research: Competencies for analysis and applications. Merrill/Pearson.

Gibson, H. L., \& Chase, C. (2002). Longitudinal impact of an inquiry-based science program on middle school students' attitudes toward science. Science education, 86(5), 693-705.

Hashmi, A., Hussain, T., \& Shoaib, A. (2018). Alignment between Mathematics Curriculum and Textbook of Grade VIII in Punjab. Bulletin of Education and Research, 40(1), 57-76.

Alleman, J., Brophy, J., \& Knighton, B. (2008). How a primary teacher protects the coherence of her social studies lessons. Social studies and the Young Learner, 21(2), 28-31.
Kolb, D. A. (1984). Experience as the source of learning and development. Upper Sadle River: Prentice Hall.

Miller, S., \& Sambell, K. (2003). What do parents feel they need? Implications of parents' perspectives for the facilitation of parenting programmes. Children \& Society, 17(1), 32-44.

Ozgelen, S., Yilmaz-Tuzun, O., \& Hanuscin, D. L. (2013). Exploring the development of preservice science teachers' views on the nature of science in inquiry-based laboratory instruction. Research in Science Education, 43(4), 15511570.

Poon, C. L., Tan, D., \& Tan, A. L. (2009). Classroom management and inquiry-based learning: Finding the balance. Science Scope, 32(9), 18.

Safdar, M. (2013). Meaningful learning and rote learning in physics: A comparative study in city Jhelum (Pakistan). Middle Eastern \& African Journal of Educational Research, 6, 60-77.

Savery, J. R. (2015). Overview of problem-based learning: Definitions and distinctions. Essential readings in problem-based learning: Exploring and extending the legacy of Howard S. Barrows, 9, 5-15.

Zareen, R., \& Kayani, M. (2014). Higher Secondary Biology Instruction in Pakistan in Constructivist Perspectives. Bulletin of Education and Research, 36(2), 39-56.

Vygotsky, L. S. (1980). Mind in society: The development of higher psychological processes. Harvard university press.

Yager, R., \& Simmons, P. (2013). Results of the Salish projects: Summary and implications for science teacher education. International Journal of Education in Mathematics Science and Technology, 1(4), 259-269. 